\title{
Problem-Based Service Learning's Effect on Environmental Concern and Ability to Write Scientific Papers
}

\author{
Sumarmi \\ Prof., Faculty of Social Sciences, State University of Malang, Indonesia, \\ sumarmi.fis@um.ac.id \\ Syamsul Bachri \\ Ph.D., Faculty of Social Sciences, State University of Malang, Indonesia, \\ syamsul.bachri.fis@um.ac.id
}

\section{Arif Baidowi}

M.Ed., SMAN 1 Campurdarat, Tulungagung, Indonesia, anginsamudera@gmail.com

\section{Muhammad Aliman}

Ph.D., Faculty of Social Sciences, State University of Malang, Indonesia, muhammad.aliman.1607219@students.um.ac.id

This study aimed to: (1) determine the effect of the problem-based service learning model based on the local wisdom of gugur gunung on the environmental concern of the students in Public Senior High School 1 Campurdarat. (2) Determine the effect of problem based service learning models on the ability to write scientific papers at Public Senior High School I Campurdarat. (3) Knowing the students' impressions of the implementation of the problem based service learning model based on the local wisdom of gugur gunung in Lake Buret, Tulungagung. The method used in this study was quasi experiment. The research design used was the post-test control group design with 2 groups: a) experimental group, which is students from class XI science 1 and b) control group, which is students from class XI science 3 of Public Senior High School I Campurdarat, Tulungagung Regency, Indonesia. Data was obtained from post-test of environmental concern and ability to write scientific papers. From the MannWhitney test using SPSS, the $\mathrm{Z}$ count value was smaller than $-\mathrm{Z}$ table $(-6.851<-$ $1.960)$, and the significance value was smaller than $\alpha(0.000<0.050)$, then the decision $\mathrm{H} 0$ was rejected which it meant there was a significant difference between the experimental group and the control group based on the measured score.

Keywords: problem based service learning model, environmental concern, local wisdom, ability to write scientific papers, learning

Citation: Sumarmi, Bachri, S., Baidowi, A., \& Aliman, M. (2020). Problem-Based Service Learning's Effect on Environmental Concern and Ability to Write Scientific Papers. International Journal of Instruction, 13(4), 161-176. https://doi.org/10.29333/iji.2020.13411a 


\section{INTRODUCTION}

Concern in maintaining the environment still needs to be improved for high school students. The environmental concern needs to be improved because it is one of the alternative ways to prevent environmental disasters such as floods, landslides, droughts and environmental pollution (Angriani, Sumarmi, Ruja, \& Bachri, 2018; Sumarmi, $2018 b$ ). Development of environmental concern was the part of the character education goals that prepare students to be able to face 21 st century competition (Sumarmi, 2016). When students have a concern attitude, students are able to think critically and be able to provide solutions to environmental problems (Motallebzadeh, Ahmadi, \& Hosseinnia, 2018). Development of environmental concern towards students starts with using the right learning model. During this time, learning using lectures, discussions, and assignments resulted in the potential that students have not been able to develop optimally (Aghajani \& Adloo, 2018; Aliman et al., 2019; Ardani, Utaya, \& Budijanto, 2016; Kasi, Sumarmi, \& Astina, 2018).

In addition having the concern for the environment, communicating in oral and written forms is one of the abilities that students must have to face the challenges in the $21 \mathrm{st}$ century (Motallebzadeh et al., 2018). Students' communication skills in writing, especially writing scientific papers can be learned through the application of learning models that develop students' critical and creative thinking skills (Kasi et al., 2018; Motallebzadeh et al., 2018). Therefore, learning innovations need to be applied in order to develop the concern for students and the ability to write scientific papers. One learning model that has been proved to be able to develop an environmental concern is the Problem-Based Service Learning (PBSL) model (Dichabeng \& Moalosi, 2016; Kasi et al., 2018; Namada, Katuse, \& Wambalaba, 2019).

Problem-Based Service Learning is a life-based learning model. This model applies knowledge into real life as a form of service directly to the community (Kaye, 2010). The PBSL model can be used to accelerate understanding of social, science, or other fields of study. In order for learning to apply the PBSL model to be more meaningful, it should be designed to be contextual in nature. Contextual learning is learning that involves local wisdom around the existence of students and schools (Sumarmi, 2018b). One of the local wisdoms around this research location is gugur gunung. Gugur gunung is a voluntary work together aimed to help fellow human beings as social beings. Therefore, this study applies the PBSL model based on the local wisdom of gugur gunung. PBSL model based on the local wisdom of gugur gunung is an alternative way to improve environmental awareness and ability to write scientific papers. The PBSL model can construct new knowledge, search topics that are studied in projects, can make decisions related to projects while helping to solve problems that exist in the community (Sumarmi, 2015).

\section{LITERATURE REVIEW}

Selecting PBSL model was based on the characteristic which is empathize students' role during learning activities. The application of PBSL model can help students discover their own concepts and understandings as well as add to the learning experience so that 
students are more motivated when following the learning process in the classroom. The PBSL model is a learning process that combines theory with community services, aimed at giving students new experiences to improve interpersonal skills, and social responsibility, critical thinking skills, problem solving skills, communication skills, and connecting students with community needs (Dichabeng \& Moalosi, 2016; Kaye, 2010).

The PBSL model proves that learning through experience is more effective to achieve maximum learning goals. This model has several advantages according to Krebs (2008) includes: a) to motivate students, b) to achieve full goals, c) to have self-satisfaction, d) to give benefit for students and society, e) to make learning to be meaningful, f) relevant, $g$ ) be able to work while studying, $h$ ) the work is meaningful, i) to connect the curriculum with the reality that exists in the community. This model also has several weaknesses. According to Peters, McHugh, \& Sendall (2006) weaknesses include: a) requires a lot of time, $b$ ) requires a lot of costs if the activities in a large project, c) there are students who do not like to do service activities, d) difficult to set the right time, e) there can be misunderstanding between the teacher and students or between students and students.

The stages of the PBSL model according to Kaye (2010) are four steps. First, the preparation stage: this step includes preparation related to explore and analyze problems that exist in the community. In exploring these problems, it can be done by doing direct observation, conducting interviews and gathering information from various sources from books, printed media, and electronic. Then, arrange programs that are appropriate and can be implemented by students accompanied with teachers who are experts in the problem. Second, the implementation stage known as 'action': this step is the activity of implementing the program that has been compiled. In this step, students have run PBSL activity programs, in which students already know the subject matter and can find solutions related problems. Third, stage of Reflection: it is an activity to look back on what has been done, see the success of the implementation of the program, and see the obstacles in the implementation of the program. Fourth, the stage of demonstration: it is a step in delivering a report to the teacher, school or community about what has been done, and reveals the success that has been achieved.

Environmental concern is part of the environmental attitudes. Environmental attitudes influenced by beliefs and intentions of environmental problems. Environmental concern can be measured by concerning for oneself, others, and surrounding (Schultz, 2001). Environmental concern is related to environmental problems (Schultz et al., 2005). Community care in maintaining their environment is driven by strong belief in values and meanings of tradition (Sumarmi, 2016). Environmental caring attitude is a form of response that is influenced by beliefs and knowledge of the environment (Pavalache-Ilie \& Unianu, 2012). Individual responses that arise can be in the form of an attitude of accepting, responding, evaluating, organizing, and becoming a character in preserving the environment. The environmental concern is closely related to environmental knowledge (Arcury, 1990). Therefore, learning that involves students directly in the field such as the PBSL model is thought to be able to influence the environmental concern and the ability to write scientific papers. 
Previous studies have proved that the application on PBSL model is useful for education. The application of the PBSL model can significantly improve the geography learning outcomes of high school students (Ardani et al., 2016), the learning outcomes increase of business students of Northeastern University, USA (Garnjost \& Lawter, 2019), and the increase of learning outcomes, discipline, and a sense of responsibility as citizens (Kim \& Lee, 2018). Furthermore, PBSL can also improve life skills (Nusanti, 2014), develop the commitment of students in Kenya to social problems, public health and environmental issues (Namada et al., 2019), increase curiosity and problem solving skills (Utami \& Roektiningroem, 2018), increase self-confidence, creativity, concern for the community among students of four state campuses in Malaysia (Mamat et al., 2019), improve students' self-efficacy in speaking in public (McNatt, 2019) and increase environmental caring attitude (Kasi et al., 2018).

In addition, previous studies that examined the application of learning models in improving the ability to write scientific papers have been carried out, including the application of the SCL model combined concept maps can improve the ability to write scientific papers (Thahroni \& Hartati, 2018), the application of content area literacy learning strategies can develop students' argumentative writing ability (Marni, Suyono, Roekhan, \& Harsiati, 2019) and peer feedback learning strategies between students (Kusumaningrum, Cahyono, \& Prayogo, 2019). The use of interactive multimedia ASSURE models can improve students 'scientific writing skills (Saputra \& Anshori, 2018), the use of a well-monitored instagram platform can develop students' writing skills in Negeri Sembilan, Malaysia and students give a positive impression of the platform's use (Shazali, Shamsudin, \& Yunus, 2019) including the use of telegram applications (Aghajani \& Adloo, 2018) and other technological literacy also have a relationship to students' writing skills (Motallebzadeh et al., 2018). The use of gamification for dental students can improve academic writing skills (Tantawi, Sadaf, \& AlHumaid, 2018), the independence of students to assess themselves can also give an influence on their competence in academic writing (Ratminingsih, Marhaeni, \& Vigayanti, 2018). However, the application of the PBSL model based on the local wisdom of gugur gunung to the environmental caring attitude and the ability to write scientific papers has not been widely studied until now.

The application of the PBSL model based on the local wisdom of gugur gunung is carried out in the Lake Buret tourist area. This lake placed in Sawo Village, Campurdarat Subdistrict, Tulungagung Regency, approximately $25 \mathrm{~km}$ from the center of Tulungagung City. The area of Lake Buret is approximately 400 meters $^{2}$. Even though it is quite small, this lake has its own uniqueness, which is a source of water that can drain 4 villages around so that in the rainy season and the dry season, the surrounding community can still grow rice throughout the year. This condition is believed to last a long time as long as the environment around the lake is maintained and sustainable by involving local communities such as the example of Kuin river management in South Kalimantan (Angriani et al., 2018).

The purpose of this study was to: (1) find out the effect of PBSL models based on the local wisdom of gugur gunung on the environmental caring attitude of the students of 
Public Senior High School I Campurdarat. (2) know the effect of the PBSL model based on the local wisdom of gugur gunung on the ability to write scientific paper of students of Public Senior High School I Campurdarat. (3) know students' impressions of the implementation of PBSL model based on the local wisdom of gugur gunung in Lake Buret Tulungagung. The research hypotheses were: (1) there is the influence of PBSL model based on the local wisdom of gugur gunung towards the environmental concern of the students of Public Senior High School I Campurdarat. (2) there is the effect of the PBSL model based on the local wisdom of gugur gunung on students's ability to write scientific paper in Public Senior High School I Campurdarat.

\section{METHOD}

The method used in this study was quasi experiment. The research design used was a post-test control group design to measure environmental concern and the ability to write scientific papers. The selection of the control group and the experiment group was based on the results of the previous daily test, two groups with almost the same value were chosen. Both groups got equal treatment on learning process in terms of goals, content, and learning material. The difference in treatment was that the experimental group got the application of the problem-based service learning model based on the local wisdom of gugur gunung and control group used conventional model using lecture, discussion and assignment methods. Learning was carried out for 5 weeks with meetings as many as 10 times including the implementation of post-test of environmental caring attitude and the final assignment in the form of scientific papers. The independent variable in this study is the PBSL model and the dependent variable is the environmental caring attitude and the ability to write scientific papers.

\section{Sample}

Tulungagung Regency placed in the southern part of East Java Province, Indonesia. Tulungagung Regency has in total 24 high schools both for public and private schools. Some high schools are located in the lowlands and in urban areas, but there is one school that located in villages and around karst hills which is SMA Negeri 1 Campurdarat. This school is $2.3 \mathrm{~km}$ from Lake Buret, which is used as a source of water for the community. Subject of this study were students from 6 classes of SMA Negeri 1 Campurdarat, Tulungagung Regency for academic year 2018-2019. The technique of taking research subjects was by choosing two research classes based on the average value that was almost the same (equivalent), namely by looking at the average daily test scores on the previous material in the field of Geography. Of the 6 research subjects, there were 2 groups that had the same average test scores, which are XI science 1 class with 33 students and XI science 3 class with 34 students. Both of these research groups were considered to have the same academic abilities. Therefore, class XI science 1 was determined as an experimental class that applied the PBSL model and class XI science 3 was defined as a control class that applied a conventional learning model.

\section{Instrument}

Data collection in this study used 4 forms of instruments, which is 1) questionnaire for environmental concern, 2) rubric instrument for assessing the ability to write scientific papers, 3) instruments for student response to the application of PBSL models, 4) PBSL 
learning devices, 5) initial observation sheet and the observation sheet when implementing PBSL, and 6) documentation that was used to collect data on the daily test scores of 6 classes that were the subject of research. The questionnaire instrument of environmental caring attitude consisted of 28 question items. Choices were adjusted according to the tendency of student answers by checking the SS column (strongly agree), S (agree), (Disagree), or STS (strongly disagree). Questionnaires for environmental caring attitude were given after students follow a conventional learning model for students in the control class and PBSL model for students in the experimental class. The rubric of assessment of the ability to write scientific papers consisted of 9 indicators of assessment. The assessment of the ability to write scientific papers was done after students do gugur gunung activities in Lake Buret for students of the experimental class and the assessment of the ability to write scientific papers was done after the discussion and presentation of material by each group ends for students in the control class. Before the environmental caring attitude questionnaire was used during post-test, the instrument was validated by two environmental education experts. Based on reliability measurement, this survey of environmental concern has sufficient reliability in Cronbach Alfa of 0.841. Instruments for assessing the ability to write scientific papers were based on scientific writing indicators that were given a value weight: title (5), background (15), problem formulation (10), purpose of writing (10), literature review (20), results and discussion ( 25), conclusions and suggestions (5), bibliography (5) and writing (5). Students' responses instrument on the PBSL application was used to obtain students' responses and impression based on their experience when PBSL conducted.

\section{Implementation}

The application of the PBSL Model was conducted in the experimental group, which is class XI Science 1, along with the learning activities.

\section{Preparation}

Students form experimental group were divided into 7 small groups in the first meeting. Then the teacher invited students to find out information about Lake Buret, which was located $1 \mathrm{~km}$ from the school. Students were invited to find environmental problems that exist around Lake Buret through interviews with residents around the school, information from books and digital media. Based on the results of preliminary observations in the Lake Buret area, the area around Lake Buret was known as the following table.

Table 1

Condition of the Lake Buret Area

\begin{tabular}{clll}
\hline No & Area & Land Slope & Vegetation \\
\hline 1. & In front of the Lake's Gate & Medium & Rare \\
\hline 2. & The front area of Lake & $\begin{array}{l}\text { Relatively flat and } \\
\text { flanked by steep slopes }\end{array}$ & $\begin{array}{l}\text { Quite dense on some lands } \\
\text { with steep slope }\end{array}$ \\
\hline 3. & Lake Area & $\begin{array}{l}\text { Relatively flat and } \\
\text { flanked by steep slopes }\end{array}$ & Quite dense \\
\hline Source: & Author observation, 2019 & &
\end{tabular}

Source: Author observation, 2019 
Based on table 1 showed condition on the slope around lake were relatively diverse from flat to steep. Whereas condition of the vegetation was quite dense, but there were some lands that still rarely vegetated, which placed on the land in front of the gate and a small portion in the area of the lake front. Types of vegetation found at the site includes: ironwoods, fruits such as longan, jackfruit, and matoa. There were some leaves waste and a few paper and plastic in the front area, the play area, and the area around the lake. If this condition continued, this will be possible to reduce quality of the lake as a tourist place and local water source. Rare condition of vegetation on medium and steep slopes was suspected to cause landslides. Meanwhile, garbage scattered on the site could damage the beauty of the lake. Therefore, concrete efforts are needed to overcome this problem. One of effort is to carry out the concern activities to the Lake Buret. After finding environmental problems, students arranged activities to solve the problems found within their groups. Based on discussion between students and teachers, the proposed solution to solve this problem was to hold a gugur gunung activity at the Lake Buret.

\section{Action}

Teachers and students looked for the right time to visit the Lake Buret. Students were in groups and guided by the teacher to go the Lake Buret to do gugur gunung activities similar like greening and cleaning up garbage. After doing the gugur gunung activity, students and teachers evaluated the activities and discussed the obstacles found for next meeting in the class.

\section{Reflection}

Some students representing the group conveyed information in front of the class regarding the activities that had been carried out. The information submitted included the success and obstacles in implementing the program.

\section{Demonstration}

In groups students made scientific reports relating to activities carried out at Lake Buret. Then the report was presented in front of the class regarding to gugur gunung activities in Lake Buret. This report was based on indicators for evaluating scientific papers that had been notified by the teacher before conducting activities in the field. This report on scientific papers was related to activities in Lake Buret with different writing themes from each group. The writing theme was linier to the problems and solutions offered by each group.

Conventional learning models was applied in the control group, which is class XI science 3. Conventional learning used was applying the lecture method, group discussions, group presentations and question and answer and the final assignment in the form of scientific papers. At the beginning of the meeting, the teacher gave lectures related to environmental subject. Then in the next meeting, students formed a group and discussed the subject and theme of the environmental problems that were told by the teacher. After discussing with groups, group representatives presented discussion reports in front of the class and other students were asked to give responses, suggestions and questions. At the end of the meeting, the teacher gave the final assignment to make 
scientific papers based on environmental problems discussed at the previous meeting. In the control group, learning process was done only in the classroom.

\section{Data Analysis}

After the data was collected, a t-test was carried out to see differences in the average student's environmental concern and scientific writing ability. Before testing, the normality assumption test was done first using the Kolmogorov-Smirnov test and the Shapiro-Wilk test, if the data used did not meet the assumption of a normality test, then the data were analyzed using substitute analysis with the Mann-Whitney Test (McKnight \& Najab, 2010 ) Test the hypothesis using the help of SPSS version 23.0 software for Windows. The normality test of the Kolmogorov-Smirnov model and the Shapiro-Wilk model can be seen in table 2 .

Table 2

Normality Test

\begin{tabular}{|c|c|c|c|c|c|c|c|}
\hline \multirow{4}{*}{ Score } & \multirow{2}{*}{ Group } & \multicolumn{3}{|c|}{ Kolmogorov-Smirnov $^{\mathrm{a}}$} & \multicolumn{3}{|c|}{ Shapiro-Wilk } \\
\hline & & Statistic & df & Sig. & Statistic & $\mathrm{df}$ & Sig. \\
\hline & Control & .161 & 34 & .026 & .952 & 34 & .144 \\
\hline & Experiment & .217 & 33 & .000 & .675 & 33 & .000 \\
\hline
\end{tabular}

Based on table 2, it can be explained that the significance value according to the normality test of the Kolmogorov-Smirnov model in the control group and experimental group was not normal $(\mathrm{p}<.05)$. The results of the normality test of the Shapiro-Wilk model showed that the control group had a significant value $(p>.05)$ which means the data on the environmental concern was normal, but the results of the normality test in the experimental class still showed abnormal results $(\mathrm{p}<.05)$. Therefore, further analysis of the value of students' environmental concern was analyzed using the normality test of the Mann-Whitney model.

\section{FINDINGS AND DISCUSSION}

\section{The Effect of PBSL Model Based on the Local Wisdom of Gugur Gunung on Environmental Concern}

PBSL learning in the experimental group aimed to determine the changes that occur in students' environmental concern. Changes in the environmental concern were tested using an analysis of independent sample t-test by comparing changes in environmental concern between the control group that applied conventional learning and the experimental group that applied PBSL learning as described in table 3.

Table 3

Control Group and Experimental Group Different Test Results

\begin{tabular}{llll}
\hline Group & Mean & SD & Significance of Normality \\
\hline Control & 85.4706 & 2.51342 & 0.026 \\
\hline Experiment & 95.5758 & 6.82381 & 0.000 \\
\hline Z Count & $=-6.851$ & \\
\hline Significance Z & $=0.000$ \\
\hline
\end{tabular}


Based on table 3, it was found that the mean control group score of 85.4706 was lower than the mean score of the experimental group of 95.5758. It was seen that there were differences in the mean between the control group and the experimental group. To find out whether there were differences in the mean between groups on the measured score, the t-test (independent sample t-test) was performed in unpaired samples. Based on the Mann-Whitney test, the $\mathrm{Z}$ calculated value was smaller than $-\mathrm{Z}$ table $(-6.851<-1.960)$, and $\mathrm{P}$-value was smaller than $\alpha(0.000<0.050)$, then the $\mathrm{H} 0$ decision was rejected which meant that there was mean difference that has significant value between groups based on measured scores.

The results of this study were consistent with previous studies conducted by Kasi et al., (2018) and Namada et al., (2019) which state that the application of the PBSL model can improve environmental awareness. The environmental concern that increased significantly in students in the experimental group was affected by PBSL learning that involved students directly in carrying out gugur gunung on Lake Buret. The existence of students directly in seeing environmental problems encouraged the growth of attitudes and responses of caring for the environment (Al-Balushi \& Al-Aamri, 2014; Nazarenko \& Kolesnik, 2018). Furthermore, in the 'action' learning stage students had design gugur gunung activity around Lake Buret area. The design of the activities students made in this study had a statistically significant influence on the environmental caring attitude and students' environmental knowledge (Nazarenko \& Kolesnik, 2018).

\section{Effect of PBSL Model Based on the Local Wisdom of Gugur Gunung Against the Ability to Write Scientific Papers}

Writing scientific papers has become a demand for students today. Competencies that must be developed by students as capital in facing the challenges of the 21 st century include being able to solve problems, be able to be critical, be able to communicate and cooperate in verbal and written clashes (Sumarmi, 2017). The differences of students' ability to write scientific papers can be explained based on table 4 .

Table 4

Average Results of Students' Ability to Write Scientific Papers

\begin{tabular}{lllll}
\hline & Group & $\mathrm{N}$ & Mean Rank & Sum of Ranks \\
\hline \multirow{3}{*}{ Score total } & Control & 34 & 17.97 & 611.00 \\
\cline { 2 - 5 } & Experiment & 33 & 50.52 & 1667.00 \\
\cline { 2 - 5 } & Total & 67 & & \\
\hline
\end{tabular}

In table 4 , it can be explained that the mean ability to write scientific papers of students who apply the PBSL model is higher than students who apply conventional learning models (lectures, discussions, question and answer and assignments). This was showed by the mean value in control group of 17.97 and the mean value on experimental group of 50.52. The difference in mean values can also be proven by the Mann-Whitney test to prove the influence of the PBSL model in improving the ability to write student scientific papers. The details can be seen in table 5 . 
Table 5

Mann-Whitney Test Results Effect of PBSL on the Ability to Write Scientific Papers

\begin{tabular}{ll}
\hline & Score total \\
\hline Mann-Whitney U & 16.000 \\
\hline Wilcoxon W & 611.000 \\
\hline Z & -6.851 \\
\hline Asymp. Sig. (2-tailed) & .000
\end{tabular}

a. Grouping Variable: Group

The results of the Mann-Whitney test as evidenced in table 5 can be explained that the significance value of 2 -tailed is $0.000<0.050$. The result of the Mann-Whitney test implies that the application of the PBSL model to the experimental group students of Public Senior High School 1 Campurdarat, Tulungagung Regency significantly influenced the ability to write scientific papers rather than the application of conventional learning models. Indicators for assessing the ability to write scientific papers need to be developed based on each student's abilities. The following are the results of the ability to write scientific papers on control group students and the experimental class described in figure 1.

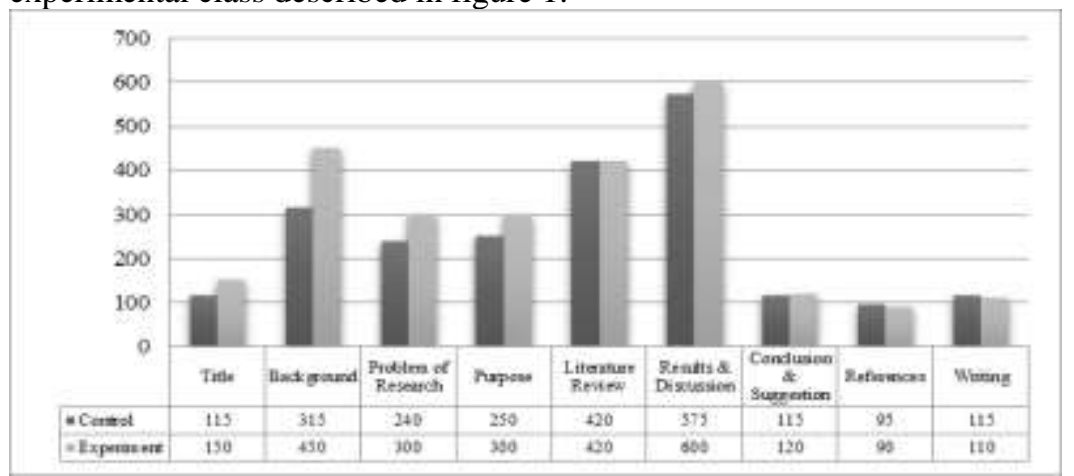

Figure 1

Average Results of the Ability to Write Scientific papers

Based on figure 1, it can be proven that there are nine assessment indicators to determine the ability to write student scientific papers. Of the nine assessment indicators, there are six assessment indicators that proved that the ability to write scientific papers in experimental group students was higher than the control group. The six indicators includes: title, background, literature review, research problem, results and discussion also conclusions and suggestions. There were 2 indicators that showed the ability to write scientific papers of control group higher than the experimental group. The two indicators included references and writing method besides the 8 indicators for assessing the ability to write different scientific papers. There was 1 assessment indicator that showed the similarity of abilities between the control group and the experimental group, which is on the literature review indicator. 
The significant difference in the ability to write scientific papers between the control group and the experimental group was caused by differences in the application of the learning model. The application of the PBSL model in the experimental group had a strong influence in developing the ability to write student scientific papers. The results of this study complement previous studies which stated that the ability to write scientific papers can be developed by applying a learning model that focused on the independence of student activities and student self-assessment (Ratminingsih et al., 2018). Significant influence in the experimental group was also caused by "Demonstration" activities. At this stage, students wrote as a report on the activities that had been carried out in the Lake Buret area. Through this writing report, students become trained to write scientific papers based on the activities they had done (Al-Balushi \& Al-Aamri, 2014). The use of social media applications as a means of communication among students in the field also had a positive impact on ability in composing vocabulary of scientific writing, this is consistent with research (Aghajani \& Adloo, 2018; Motallebzadeh et al., 2018; Shazali et al., 2019) which stated that Telegram, Instagram and other technological literacy applications can improve student performance in writing scientific papers. Student activities in reporting scientific papers in front of the class (demonstration stage) can also develop self-efficacy, communication between students and collaboration (Motallebzadeh et al., 2018).

The activity of the PBSL model that influenced the increased ability to write scientific papers was the activity of "Reflection". This activity can form student life skills because students evaluated the activities that had been carried out. Through the "Reflection" activity, students were taught to be able to commit in solving social and environmental problems and were able to find solutions to these problems (Namada et al., 2019; Nusanti, 2014). The activities of students who provide feedback to each other at the "Preparation" stage had an impact on the increasing proficiency in writing student scientific papers. This is in accordance with the results of research which stated that discussion activities (Peer feedback) among students and literacy content areas in small groups can improve the performance of writing scientific papers (Kusumaningrum et al., 2019; Marni et al., 2019).

Knowing the Impression of Students on the Implementation of the PBSL Model Based on The Local Wisdom of Gugur Gunung in Lake Buret Tulungagung.

Gugur Gunung is a voluntary work together aimed to help fellow human beings as social beings. Gugur Gunung is also called mutual cooperation. The term gugur gunung was adopted from the Javanese language, that is gugur gunung tegese makaryo sesarengan kangge tujuan sosial. It means that gugur gunung is a social concept of the Archipelago's heritage consisted of togetherness, mutual help, hospitality, work together without rewards and selfishness. For example, community service builds an emergency bridge together, builds a house together, helps other residents to work without asking for rewards. Mutual cooperation in certain contexts will create a spirit of community unity. In this study, gugur gunung was done by reforesting around Lake Buret in Campurdarat District, Tulungagung Regency, Indonesia. The following is a picture of the location of the Lake Buret. 


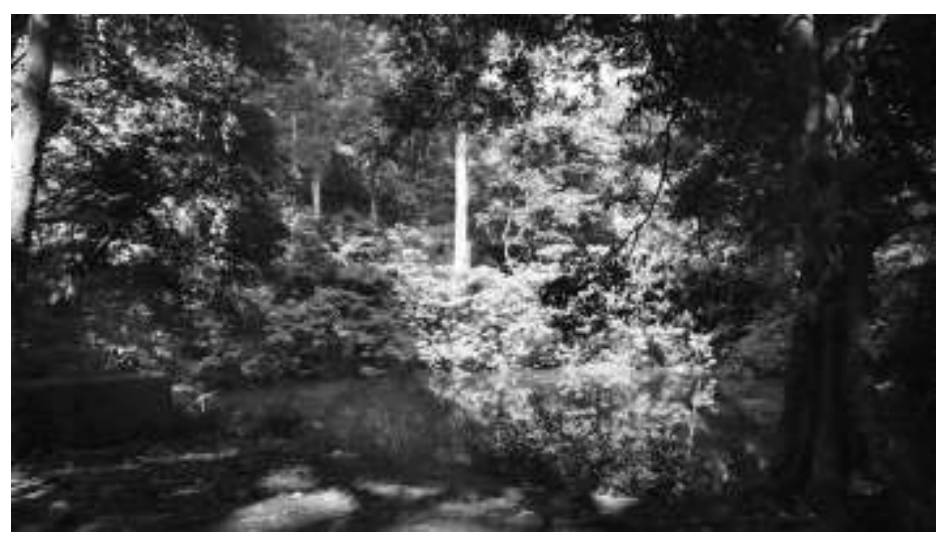

Picture 1

Location of Lake Buret

The gugur gunung activity carried out by students from XI science 1 at Lake Buret included reforestation and community service to clean up garbage. Greening is a term used to describe tree planting activities. Greening is done by the community as one of the ways to preserve nature (local wisdom), considering that trees have many benefits, not only for the environment, but also for living things both humans and animals (Sumarmi, 2018b). Trees planted are from various kinds. Trees planted are trees that have many functions, such as storing water in the roots, having versatile wood, or having many fruits. Some of the trees planted in the greening activities include starfruit trees (Averrhoa Carambola), sapodilla kecik (Manilkara Kauki), suren (Toona), and mahogany (Swietenia Mahagoni). In addition to reforesting, students also do waste cleaning in the Lake Buret tourist area. This is done to develop students' sense of love for the environment, and concern towards the environment.

In addition to providing benefits for preserving the environment, reforestation also provides benefits for the welfare of the community. Community welfare cannot be achieved if the community does not optimize its potential in its environment and integrates community elements in managing resources sustainably (Angriani et al., 2018). Community welfare is related to conditions that are comfortable, good, prosperous and fulfilled of all needs (Sumarmi, 2018a). The community can enjoy various benefits from reforestation as mentioned earlier. Matters relating to the welfare of the community are obtained through the implementation of reforestation. Green plants around us are one of the potentials that can bring many benefits if we process them properly. Therefore, improving the quality of environmental caring attitude of high school students is also very necessary in managing the environment in order to achieve public welfare. The distance between Public Senior High School I Campurdarat with Lake Buret is about 2,3 km, this close distance can be used for students of Public Senior High School 1 Campurdarat to always do gugur gunung activities as a real form of concern for high school students to their environment. During applying this PBSL model, the experimental group students responded to the learning process. Student responses to the PBSL model can be seen in table 6 . 
Table 6

Student Response to the Application of Problem-Based Service Learning Models

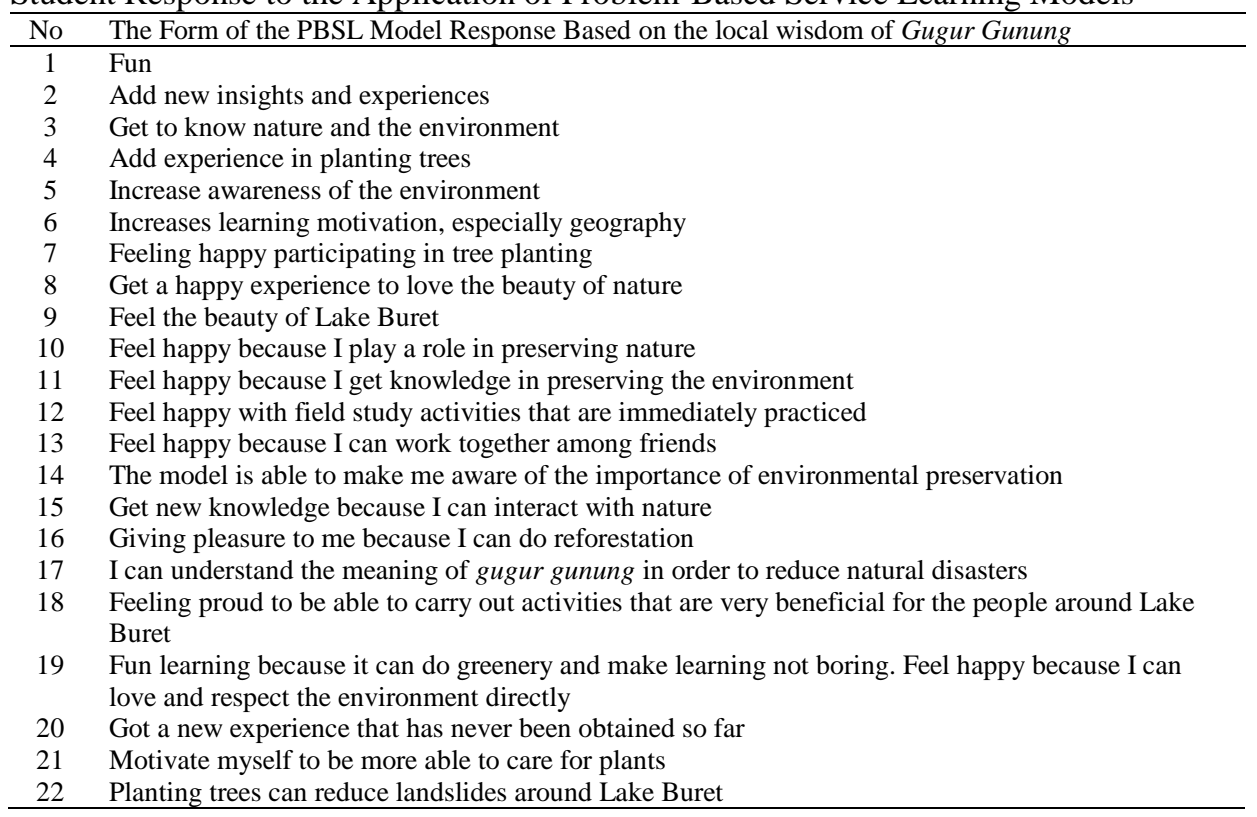

Student responses described in table 6 show that in general the experimental group students were pleased with the application of the PBSL model. The application of this learning model provides many benefits to students, including increasing knowledge, motivation and concern in preserving the environment. The gugur gunung activities conducted by students provide new experiences that reforestation and voluntary work to clean up trash are useful to prevent natural disasters.

\section{CONCLUSION}

In general, learning activities with PBSL model based on the local wisdom of gugur gunung on Lake Buret have run smoothly as expected. The event started from the gugur gunung activities by cleaning the area around Lake Buret, to reforestation activities around the slopes of the lake area. From the data analysis using the Mann-Whitney test, the calculated $\mathrm{Z}$ value was smaller than $-\mathrm{Z}$ table which means that $\mathrm{H} 0$ was rejected, it shows that there are significant differences in environmental concern and the ability to write scientific papers between the application of the PBSL model based on the local wisdom of gugur gunung and the application of conventional learning models using the method of lecture, discussion, and assignment of tasks based on the measured score. The gugur gunung activities carried out by students can increase concern in preserving the Lake Buret area.

\section{IMPLICATIONS AND RECOMMENDATIONS}

Based on the conclusions, theoretically this research has implications for learning that is built on direct experience in the field. It can develop communication skills in the form of 
writing and shape the environmental concern character. Practically, this study proves that the PBSL model is effective in increasing environmental concern and the ability to write scientific papers. The recommendations are intended for teachers, lecturers and practitioners of geography education to apply the PBSL model in developing environmental concern and improving skills in writing scientific papers. The next researcher can develop research such as the application of the PBSL model to other 21st century skills such as critical thinking, creative thinking, and spatial thinking.

\section{REFERENCES}

Aghajani, M., \& Adloo, M. (2018). The Effect of online cooperative learning on students' writing skills and attitudes through telegram application. International Journal of Instruction, 11(3), 433-448. https://doi.org/10.12973/iji.2018.11330a.

Al-Balushi, S. M., \& Al-Aamri, S. S. (2014). The effect of environmental science projects on students' environmental knowledge and science attitudes. Int. Res. in Geog. and Environ. Edu., 23(3), 213-227. https://doi.org/10.1080/10382046.2014.927167.

Aliman, M., Budijanto, B., Sumarmi, S., \& Astina, I. K. (2019). Improving Environmental awareness of high school students' in Malang city through earthcomm learning in the geography class. International Journal of Instruction, 12(4), 79-94. https://doi.org/10.29333/iji.2019.1246a.

Angriani, P., Sumarmi, Ruja, I. N., \& Bachri, S. (2018). River management: The importance of the roles of the public sector and community in river preservation in Banjarmasin (A case study of the Kuin River, Banjarmasin, South KalimantanIndonesia). Sustainable Cities and Society, 43, 11-20. https://doi.org/10.1016/j.scs.2018.08.004.

Arcury, T. (1990). Environmental attitude and environmental knowledge. Human Organization, 49(4), 300-304. https://doi.org/10.17730/humo.49.4.y6135676n433r880.

Ardani, A., Utaya, S., \& Budijanto, B. (2016). Pengaruh Model Pembelajaran ServiceLearning terhadap Hasil Belajar Geografi SMA. Jurnal Pendidikan: Teori, Penelitian, dan Pengembangan, 1(11), 2145-2151. https://doi.org/10.17977/jp.v1i11.7977.

Dichabeng, P., \& Moalosi, R. (2016). Acquisition of graduate attributes through the service learning pedagogy: The case of the University of Botswana. Global Journal of Engineering Education, 18(2), 136-141.

Garnjost, P., \& Lawter, L. (2019). Undergraduates' satisfaction and perceptions of learning outcomes across teacher- and learner-focused pedagogies. The International $J$ of Management Education, 17(2), 267-275. https://doi.org/10.1016/j.ijme.2019.03.004.

Kasi, K., Sumarmi, \& Astina, I. K. (2018). Pengaruh Model Pembelajaran Service Learning terhadap Sikap Peduli Lingkungan. Jurnal Pendidikan: Teori, Penelitian, dan Pengembangan, 3(4), 437-440.

Kaye, C. B. (2010). The Complete guide to service learning: Proven, Practical ways to engage students in civic responsibility, academic curriculum, \& social action. revised \& updated second edition. Retrieved from http://www.freespirit.com. 
Kim, E., \& Lee, Y.-J. (2018). Serve as you learn: Problem-based service-learning integrated into a product innovation and management class. International Journal of Costume and Fashion, 18(2), 29-43. https://doi.org/10.7233/ijcf.2018.18.2.029.

Krebs, M. M. (2008). Service-learning: What Motivates k-12 teachers to initiate servicelearning projects? Curriculum and Teaching Dialogue, 10(1), 135-149.

Kusumaningrum, S. R., Cahyono, B. Y., \& Prayogo, J. A. (2019). The effect of different types of peer feedback provision on EFL students' writing performance. Int Journal of Instruction, 12(1), 213-224. https://doi.org/10.29333/iji.2019.12114a.

Mamat, M., Amran, N. N., Ismail, Z., Ibrahim, M., Ishak, H., \& Baba, S. (2019). Service-learning in Malaysia: Practice and implementation in four public universities. International Journal of Civil Engineering and Technology, 10(4), 1682-1691.

Marni, S., Suyono, S., Roekhan, R., \& Harsiati, T. (2019). Critical thinking patterns of first-year students in argumentative essay. Journal for the Education of Gifted Young Scientists, 7(3), 733-747. https://doi.org/10.17478/jegys.605324.

McKnight, P. E., \& Najab, J. (2010). Mann-whitney u test. https://doi.org/10.1002/9780470479216.corpsy0524.

McNatt, D. B. (2019). Enhancing public speaking confidence, skills, and performance: An experiment of service-learning. The International Journal of Management Education, 17(2), 276-285. https://doi.org/10.1016/j.ijme.2019.04.002.

Motallebzadeh, K., Ahmadi, F., \& Hosseinnia, M. (2018). Relationship between 21st century skills, speaking and writing skills: A structural equation modelling approach. International of $J$ Instruction, 11(3), 265-276. https://doi.org/10.12973/iji.2018.11319a.

Namada, J. M., Katuse, P., \& Wambalaba, F. W. (2019). International education, diversity exposure, and cross-cultural engagements. In B. Smith (Ed). Mission-driven approaches in modern business education (pp.273-288). PA: IGI Global.

Nazarenko, A. V., \& Kolesnik, A. I. (2018). Raising environmental awareness of future teachers. Int J of Instruction, 11(3), 63-76. https://doi.org/10.12973/iji.2018.1135a.

Nusanti, I. (2014). Strategi Service Learning Sebuah Kajian untuk Mengembangkan Kegiatan Pembelajaran. Jurnal Pendidikan dan Kebudayaan, 20(2), 251-260-260. https://doi.org/10.24832/jpnk.v20i2.142.

Pavalache-Ilie, M., \& Unianu, E. M. (2012). Locus of control and the pro-environmental attitudes. Procedia - Social and Behavioral Sciences, 33, 198-202. https://doi.org/10.1016/j.sbspro.2012.01.111.

Peters, T., McHugh, M. A., \& Sendall, P. (2006). The benefits of service learning in a down-turned economy. Int J of Teaching and Learning in Higher Edu, 18(2), 131-141.

Ratminingsih, N. M., Marhaeni, A. A. I. N., \& Vigayanti, L. P. D. (2018). Selfassessment: The effect on students' independence and writing competence. Int Journal of Instruction, 11(3), 277-290. https://doi.org/10.12973/iji.2018.11320a. 
Saputra, D. Y., \& Anshori, D. S. (2018). Pengembangan Multimedia Interaktif Model ASSURE untuk Meningkatkan Kemampuan Menulis Karya Tulis Ilmiah [Development of the ASSURE Interactive Multimedia Model to Improve the Writing Ability of Scientific Writing]. Seminar Internasional Riksa Bahasa, 941-950.

Schultz, P. W. (2001). The structure of environmental concern: Concern for self, other people, and the biosphere. Journal of Environmental Psychology, 21(4), 327-339. https://doi.org/10.1006/jevp.2001.0227.

Schultz, P. W., Gouveia, V. V., Cameron, L. D., Tankha, G., Schmuck, P., \& Franěk, M. (2005). Values and their relationship to environmental concern and conservation behavior. Journal of Cross-Cultural Psychology, 36(4), 457-475. https://doi.org/10.1177/0022022105275962.

Shazali, S. S., Shamsudin, Z. H., \& Yunus, M. (2019). Instagram: A Platform to develop student's writing ability. International Journal of Academic Research in Business and Social Sciences, 9(1), 88-98. https://doi.org/10.6007/IJARBSS/v9-i1/5365

Sumarmi. (2015). Model-model Pembelajaran Geografi. Yogyakarta: Aditya Media.

Sumarmi. (2016). A Study of local wisdom of balinese aga and samin people to develop environmental awareness characteristics. Advances in Social Science, Education and Humanities Research, 79, 201-205.

Sumarmi. (2017). Influence of local wisdom-based blended learning module for environmental geography towards problem-solving skill. Advances in Soc Sci, Edu and Humanities Research, 164, 157-160. https://doi.org/10.2991/icli-17.2018.30.

Sumarmi. (2018a). The Local genius of tengger people in conserving forest and increasing economic benefits using agroforestry system. IOP Conf S: Earth and Environ Science, 145(1), 012135. https://doi.org/10.1088/1755-1315/145/1/012135.

Sumarmi. (2018b). Understanding the forest conservation society actions "tengger" ethnic based local wisdom "sesanti panca setya" in East Java - the Republic of Indonesia. Advances in Social Science, Education and Humanities Research, 226, 1623-1627. https://doi.org/10.2991/icss-18.2018.337.

Tantawi, M. E., Sadaf, S., \& AlHumaid, J. (2018). Using gamification to develop academic writing skills in dental undergraduate students. European Journal of Dental Education, 22(1), 15-22. https://doi.org/10.1111/eje.12238.

Thahroni, T., \& Hartati, R. (2018). Pengaruh Metode SCL Dipadu Peta Konsep terhadap Pemahaman Bacaan dan Menulis Karya Ilmiah dalam Era MEA. Psychopolytan (Jurnal Psikologi), 2(1), 58-64.

Utami, P. A., \& Roektiningroem, E. (2018). Pengaruh Strategi Service Learning Bermodel Problem Based Learning terhadap Problem Solving Skills dan Sikap Ingin Tahu Siswa [Impact of Modeled Learning Service Strategies on Problem Based Learning on Problem Solving Skills and Attitudes of Curiosity Students]. Pend. Ilmu Pengetahuan Alam - S1, 7(7), 386-392. 